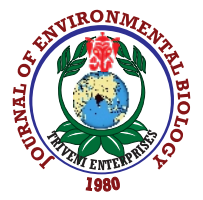

\title{
Analysis of the areas suitable for ecotourism using Geographical Information Systems: Example of Narman District (Erzurum) Turkey
}

\section{E. Akpınar Külekçi ${ }^{1 *}$ and A. Koç ${ }^{2}$}

${ }^{1}$ Faculty of Architecture and Design, Department of Landscape Architecture, Ataturk University, Yakutiye- Erzurum, 25240, Turkey ${ }^{2}$ Dicle University, Diyarbakır Vocational School of Technical Sciences, Department of Park and Garden Plants, Diyarbakır, 21000, Turkey

*Corresponding Author Email : eakpinar@atauni.edu.tr

\begin{abstract}
Aim: To protect and use the existing natural and cultural resources of Narman district with a sustainable tourism perspective and evaluate an environmentally sensitive tourism planning approach.

Methodology: Natural and cultural resource values of the district were measured using Arc GIS 10.2 from GIS (Geographical Information Systems) software. For this purpose, elevation, accessibility, proximity to river and stream water beds, geological structure, fauna, slope, drainage, large soil groups and land use maps were drawn and their suitability values were determined. The data obtained was analyzed using map overlaying and appropriate areas for potential ecotourism of the area; the coverage rates were also determined and mapped.
\end{abstract}

Results : This study revealed that 9027 hectares (7.08\%) of the district are quite appropriate for such activities, 79050 hectares are (62\%) appropriate, $33379,5$ hectares (26.18\%) are less appropriate and 6043 hectares ( $4.74 \%)$ are not appropriate.

Interpretation: This study showed that Narman Fairy Chimneys and their immediate vicinity, high mountainous and rocky areas as well as valley plains, areas near the rivers and stream water beds and forest areas have important potential for ecotourism.

Key words: Ecotourism, Geographical Information System, Narman (Erzurum), Suitability Analysis, Turkey

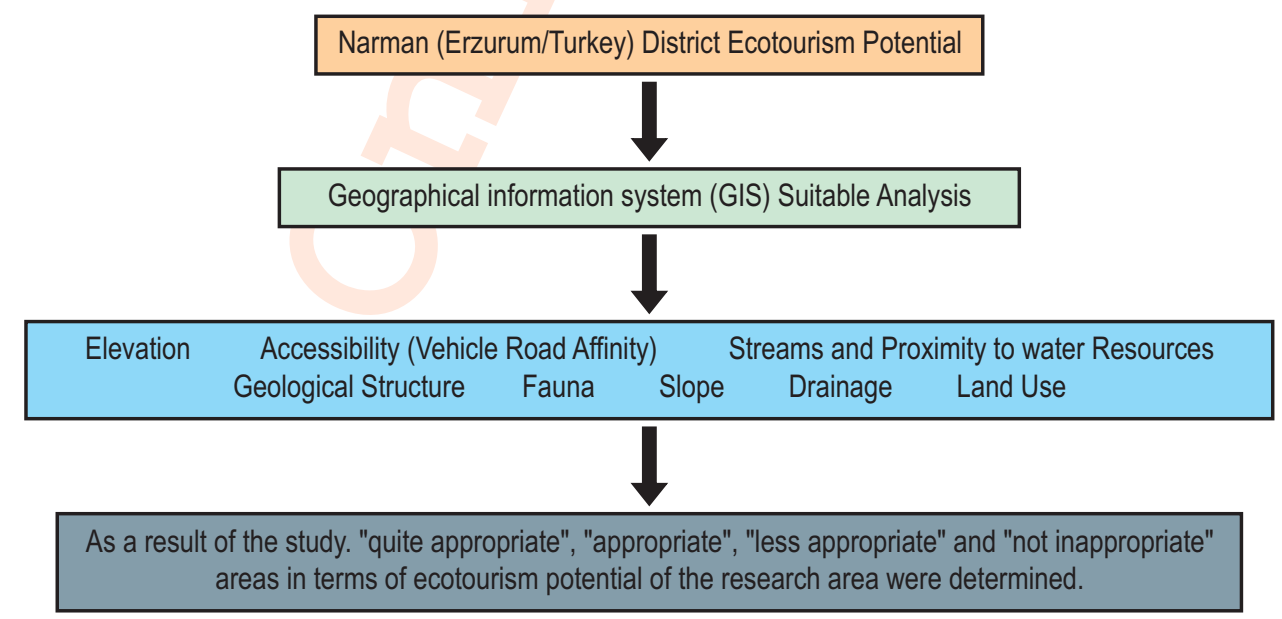

How to cite : Külekçi Akpınar, E. and A. Koç: Analysis of the areas suitable for ecotourism using Geographical Information Systems: Example of Narman District (Erzurum) Turkey. J. Environ. Biol., 41, 293-301 (2020). 


\section{Introduction}

Tourism patterns have changed considerably in recent years due to rapid economic, social and technological developments in the world. The expectations for new types of tourism are becoming more evident over the time. These include active holidays close to nature in a good room with good services, with modest facilities and foremost among these pristine environments situated away from the usual tourist centers dominated by the sea, sun and sand triangle. World Tourism Organization (WTO), United Nations Environment Program (UNEP) and United Nations Development Program (UNDP), together with various organizations and academic circles around the world as well as in Turkey analyze the subjects such as search for practical solutions for solving the environmental problems and ensuring sustainable development by approaching them from different perspectives, and they are constantly working on the subjects of environment and tourism. The quality of life now and in the future can be followed in a balanced environment created by a combination of natural and architectural landscapes. Regions making natural environment attractive from now will be more suitable in future. Recent studies stress on making tourism more sustainable (Wang et al., 2016; Aşur and Alphan, 2017; Vural, 2019; Akpinar Külekçi, 2012). In 1991, the International Ecotourism Society (TIES) described ecotourism as one of the main definitions of ecotourism as; "the travel which supports the welfare of local citizens and fits with natural areas, mainly protecting the environment (environment friendly)". Another definition describes it as "a type of tourism which serves generally to small groups of people and provides accommodation as well as catering services generally through small or medium size local companies" (Özbek, 2004). Osman et al. (2018) argued that ecotourism benefits from the environment, society, culture and economy of the attractive areas and local communities, providing the best solution in the long-run to protect and promote local natural and cultural diversity.

Physical planning is an approach based on the fact that the features of natural environment are guiding factor in planning studies. The investigations carried out at different scales for different purposes in the planning studies create a scope which is important as it pursues public interest because it considers the balance of protecting and using, sustainable use of resources and maintenance of the continuity of use without requiring renewal. This type of planning can be improved as it provides social and economic advantages. The results of physical planning also play a leading role in decision-making for local and public administrators in all kinds of work related to physical space. In the management of visuall and scape resources, during land use planning and design work, current state of protection, repair, strengthening and development of land is emerging (Aşur, 2019).

GIS (Geographical Information System) has the qualification of gathering, storing, analyzing, importing the results, updating, developing the data related to the features of natural environment, properties of the goals of planning and resources and opportunities, transfer, visualization and presentation of data, and realization of studies carried out in a

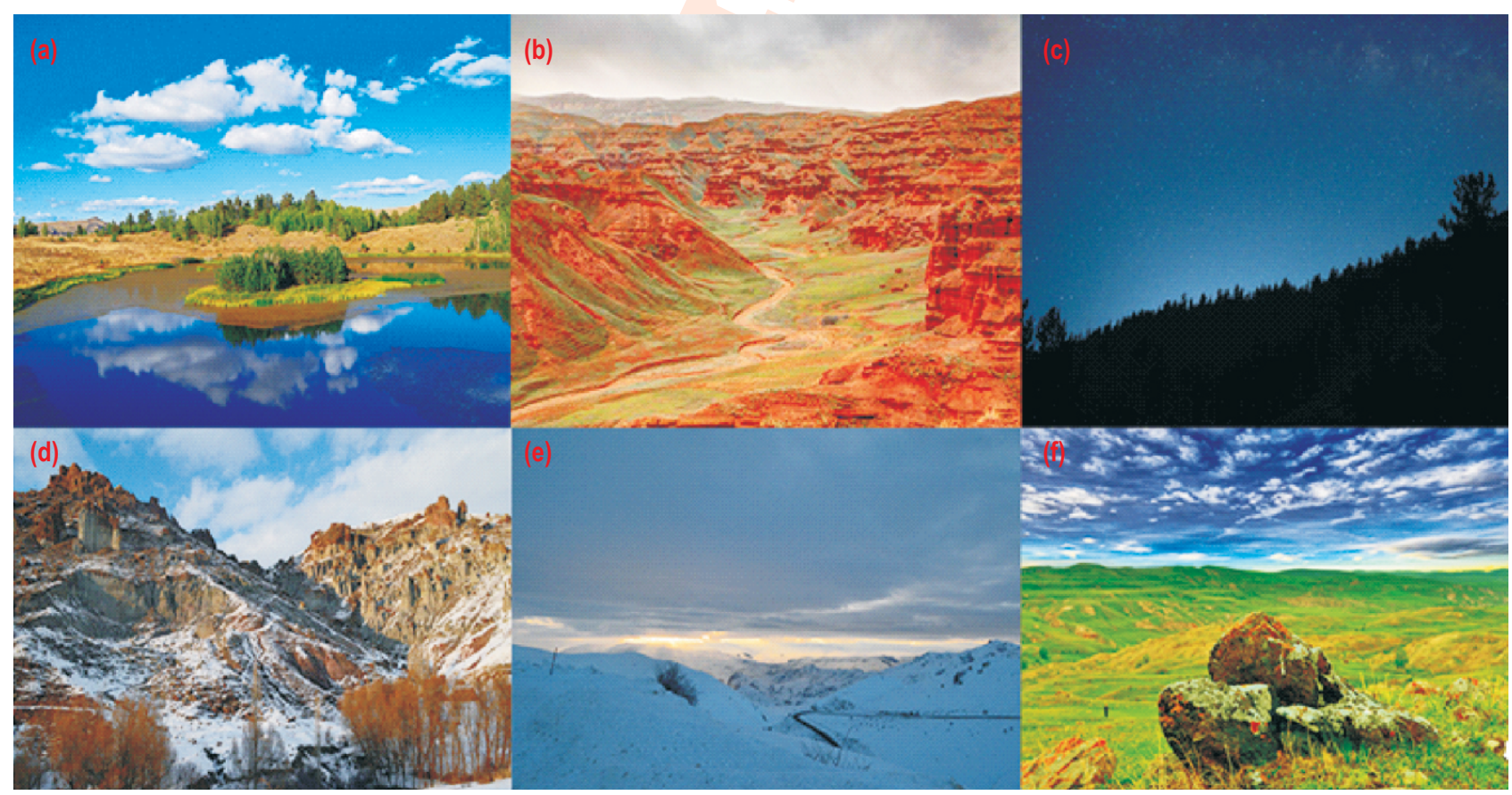

Fig. 1 : Nature scenes from Narman district (Anonymous 2018a) [a). Fivelakeslocation b) Fairy Chimneys c) Lakesand forest area d) Plateau road (Kamışözü District location) e) Kireçli Mountain f). Redchurch area (Fairy Chimney Formation Area)] (Source: www.narman.bel.tr). 
short time, in the most economical way, with least possible labor (Turoglu 2005).

The Narman district in Erzurum and its surroundings was selected as research area. The area has a rich visual landscape resources with mountains, forests, highlands, shores, lakes and rivers (Fig. 1). Both flora and fauna in the area, as well as interesting geological formations and canyons form important natural landscape wealth of the region in terms of eco tourism.

The aim of this study was to protect and use the present natural and cultural resources of Narman district with a perspective of sustainable tourism, and develop it with an environmentally sensitive tourism planning approach.

\section{Materials and Methods}

Narman District is located between $40^{\circ} 22^{\prime \prime} \mathrm{O}^{\prime} \mathrm{N}$ latitudes and $41^{\circ} 55^{\prime \prime} 59^{\prime} \mathrm{E}$ longitudes, lying at a distance of $96 \mathrm{~km}$ to Erzurum province, covering an area of $1275 \mathrm{~km}^{2}$ and at altitude $1640 \mathrm{~m}$ (Anonymous 2018b) (Fig. 2). Except for the wide valley floor where the district center is established, the lands are mountainous. The waters coming from the mountains around the center of the district combine with Big River in the valley floor and then mix with the Oltu River (Özav, 1987; Anonymous 2018c).

The methods of GIS based evaluation factors were used for analyzing of lands suitable for tourism as well as recreational rural areas and their conformity factors analysed benefitting from their sub-factors. These comply with the use of natural and cultural resource values in terms of ecotourism as proposed by McHarg (1992), Makropoulos et al. (1999); Collins et al. (2001), Joerin et al. (2001), Laskar (2003), Moldovanyi (2003), Malczewski (2004), Kiziloglu et al. (2006),Kiper and Arslan (2007), Zengin and YıImaz (2008), Khoi and Murayama (2010), Cengiz (2013) and Aklıbaşında and Bulut (2014). The method was developed according to ecological, economic and cultural factors. The expert opinions were taken into consideration for selecting area necessary for performing some alternative tourism activities. With this method, certain planning factors important for ecotourism activities such as slope, topography and water resources were classified and subdivided into sub-factors and suitable maps created in order of priority and value ranges were

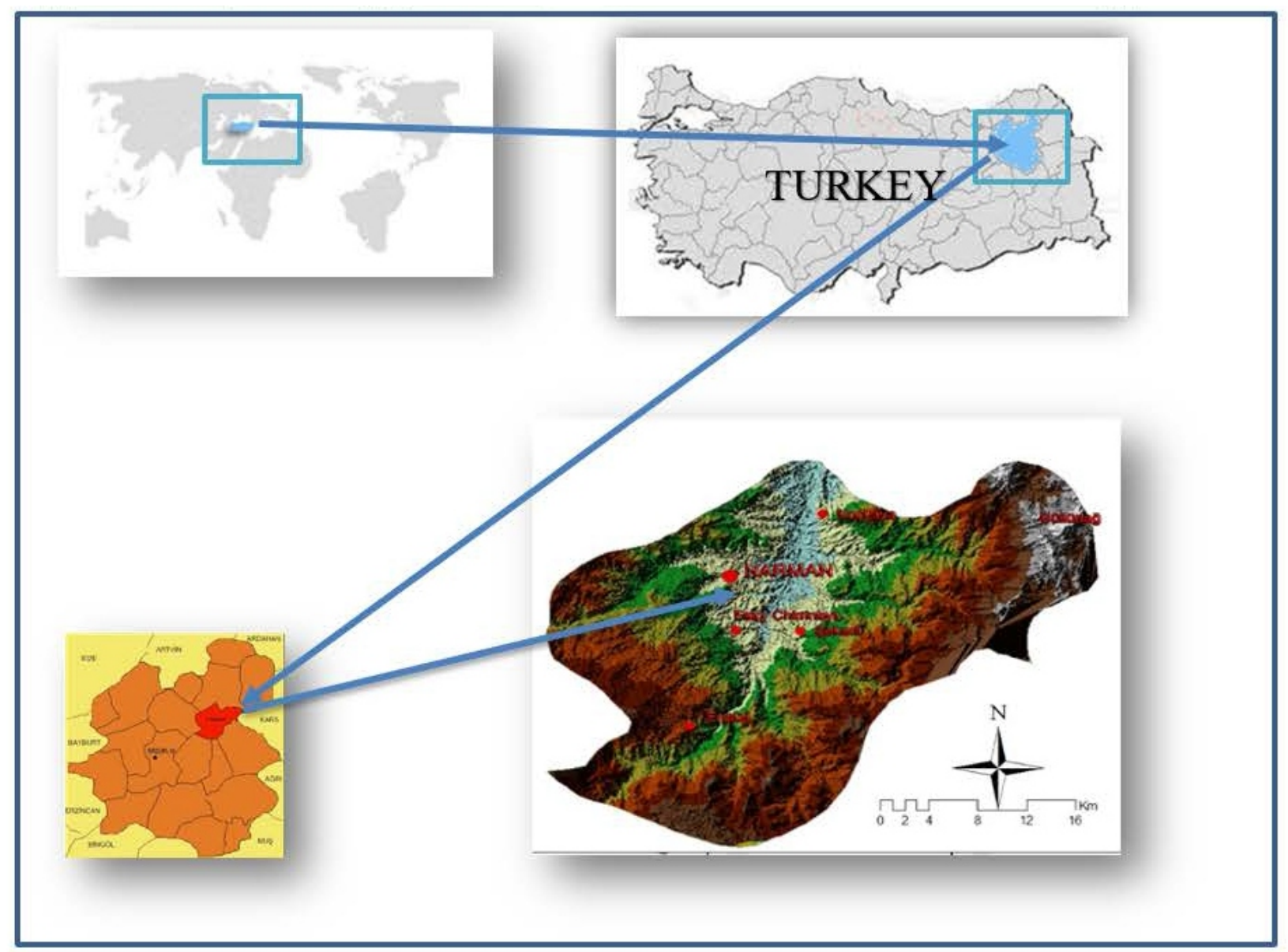

Fig. 2 : Location of study area (original). 
Table 1 : Factors and values determining the potential use of study area for ecotourism

\begin{tabular}{|c|c|c|}
\hline Assessment factor & Sub-criteria & Suitability degree \\
\hline \multirow[t]{4}{*}{ Elevation } & $<1500 m$ & 4 \\
\hline & $15001-2000 m$ & 3 \\
\hline & $2001-2500 \mathrm{~m}$ & 2 \\
\hline & $2501-2918 \mathrm{~m}$ & 1 \\
\hline \multirow[t]{4}{*}{ Accessibility (Vehicle Road Affinity) } & $0-1000 \mathrm{~m}$ & 4 \\
\hline & $1001-2000 \mathrm{~m}$ & 3 \\
\hline & $2001-3000 \mathrm{~m}$ & 2 \\
\hline & $>3000 \mathrm{~m}$ & 1 \\
\hline \multirow[t]{4}{*}{ Streams and Proximity to Water Resources } & $0-300 \mathrm{~m}$ & 4 \\
\hline & $301-700 m$ & 3 \\
\hline & $701-1000 m$ & 2 \\
\hline & $>1000 \mathrm{~m}$ & 1 \\
\hline \multirow[t]{2}{*}{ Geological structure } & Lithological structure (rock patterns-color) & 4 \\
\hline & Tectonic structures (curved surfaces) & 1 \\
\hline \multirow[t]{2}{*}{ Fauna } & Areas of importance in terms of fauna features & 4 \\
\hline & Other fields & 1 \\
\hline \multirow{6}{*}{ Slope } & $\% 0-2$ & 4 \\
\hline & $\% 3-6$ & 4 \\
\hline & $\% 7-12$ & 3 \\
\hline & $\% 13-20$ & 3 \\
\hline & $\% 21-30$ & 2 \\
\hline & $>\% 30$ & 1 \\
\hline \multirow{2}{*}{ Drainage } & No drainage problem & 4 \\
\hline & Drainage problem & 1 \\
\hline \multirow[t]{2}{*}{ Large soil groups } & Brown forest soils and alluvial soils & 1 \\
\hline & Basaltic soils & 4 \\
\hline \multirow[t]{4}{*}{ Field uses } & Shrubbery-forest & 4 \\
\hline & Residential areas & 3 \\
\hline & Meadows and pastures & 2 \\
\hline & Agriculture & 1 \\
\hline
\end{tabular}

defined. Layers formed by each of the maps were then overlaid on top of each other to determine the most appropriate ecotourism activity areas in the district. Within the scope of this study, proper areas where people would prefer to use most and which would be suitable to use while considering the natural and cultural characteristics of the area were determined.

A detailed literature survey (research studies, articles, magazines, projects, etc.) was conducted while preparing the data base. Field observations and inspections were made through field investigations, and socio-cultural and physical analysis of the investigation area was carried out. The following materials were used for creating the database.

- DEM (Digital Elevation Model) maps for classification of height and inclination groups; • General Directorate of Mineral Research and Exploration (MTA) Geological Map of Turkey; - Ministry of National Defense Map General Command of Mapping 1993 $1 / 25,000$ scale raster topographic maps; • Erzurum Governorship GIS Center Numerical data of district boundaries and village locations of the investigation area; • Erzurum General Directorate of Forestry Sustainable Forest Criteria and Indicators Report; • In area usage maps were reduced from CORINE level 3 to level $1 ; \cdot$ General Directorate of Rural Services 1/25,000 scale raster data maps; $\bullet$ Satellite photos and maps of the area.

$1 / 25.000$ scale raster format maps in the study Arc GIS were converted into vector data with 10.2 program for analysis. The current database, which best reflects the current situation of the area, was created by digitizing the changes that took place over time on the last map. Even though the maps used as the bases in creating the database were produced at different dates, it is important to collect the data that best reflects the current state of the point area and digitize them with great care. Although, raster maps are being digitized in electronic / computer environment, small mapping mistakes that seem small can actually cause data loss in miles and kilometres. In this study, necessary attention was paid to the subjects that directly affect the results of analysis. In the analysis of "suitability of the area to ecotourism in terms of natural and cultural resource values" height, accessibility (closeness to the road), proximity to river and stream water beds, geological structure, fauna, slope, drainage, large soil groups and plant area usage were taken as basis. In 
addition, while determining potential assessment factors and degrees in ecotourism in the study area, previous studies were evaluated fully together with other literature sources, expert opinions on the subject, on-site observations and examinations, one-to-one interviews with local people and field surveys of natural and cultural resource values (Table 1).

Conformity degree are listed as follows: (4) Quite appropriate, (3) Appropriate, (2) Less suitable, (1) Not appropriate.

\section{Results and Discussion}

Narman district (Erzurum) is located in the north east of Kars province in the Eastern Anatolian Region. It has two main road connections to Erzurum. It is established in the river basin between the Karga Pazarı mountains extending in the northeastsouthwest direction in the north and the Güllü Mountains extending in the northeast-southwest direction in the south. The territory of the province borders with Sarıkamış of Kars in the east, Tortum in the west, Oltu in the north, Horasan and Hasan castle districts in the south and southeast. It is located in the starting

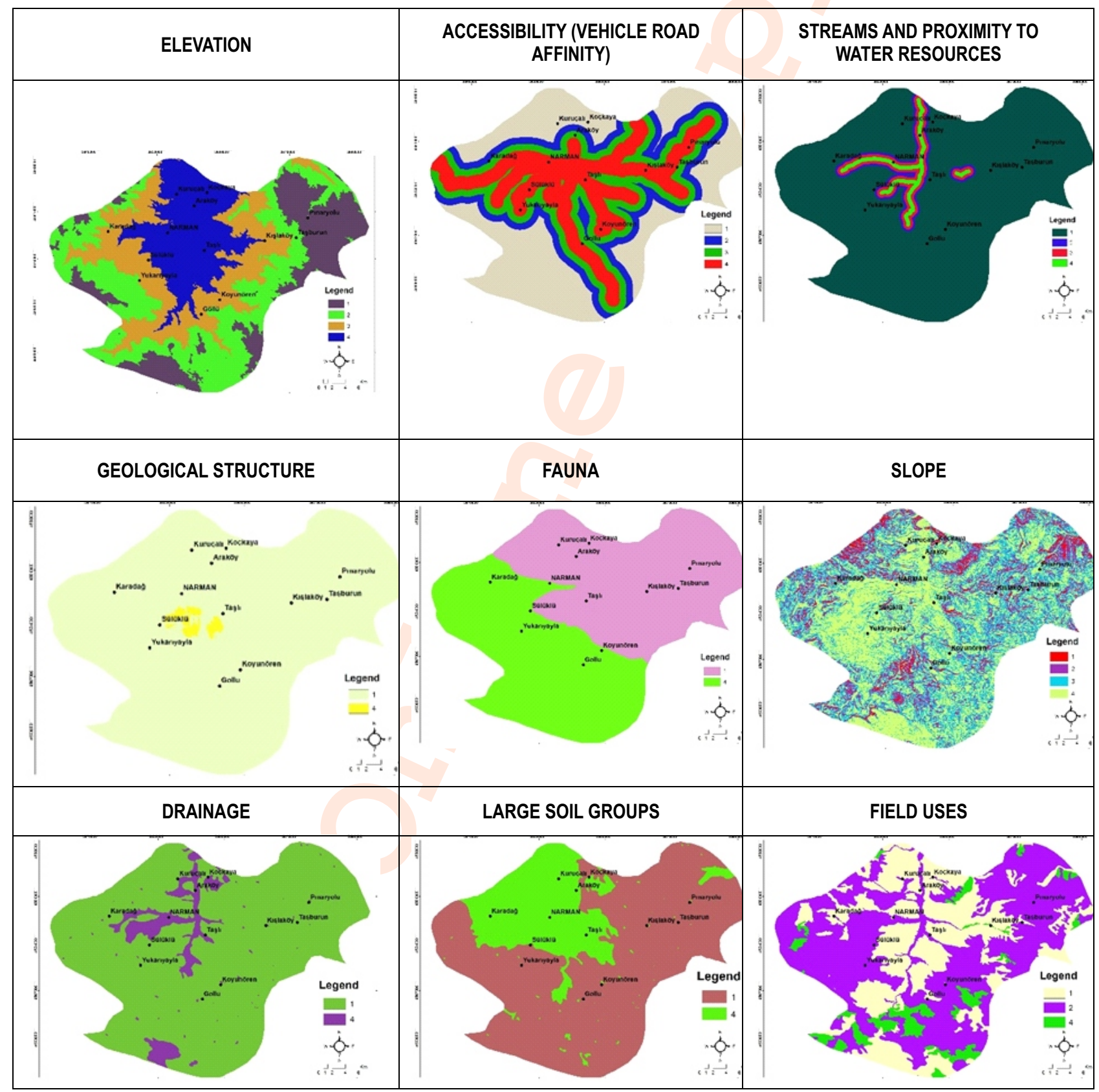

Fig. 3 : Suitable maps for assessment factors for determining the use of potential ecotourism area. 
Table 2 : Footprints and proportions of assessment factors that belong to the investigation site according to the level of conformity

\begin{tabular}{llll}
\hline Suitability status & Suitability range & Field size (ha) & \% Value \\
\hline Quite appropriate & $9-12$ & 9027 & 7,08 \\
Appropriate & $13-18$ & 79050 & 62 \\
Less suitable & $19-23$ & 33379,5 & 26,18 \\
Notappropriate & $24-31$ & 6043,5 & 4,74 \\
TOTAL & & 127500 & 100 \\
\hline
\end{tabular}

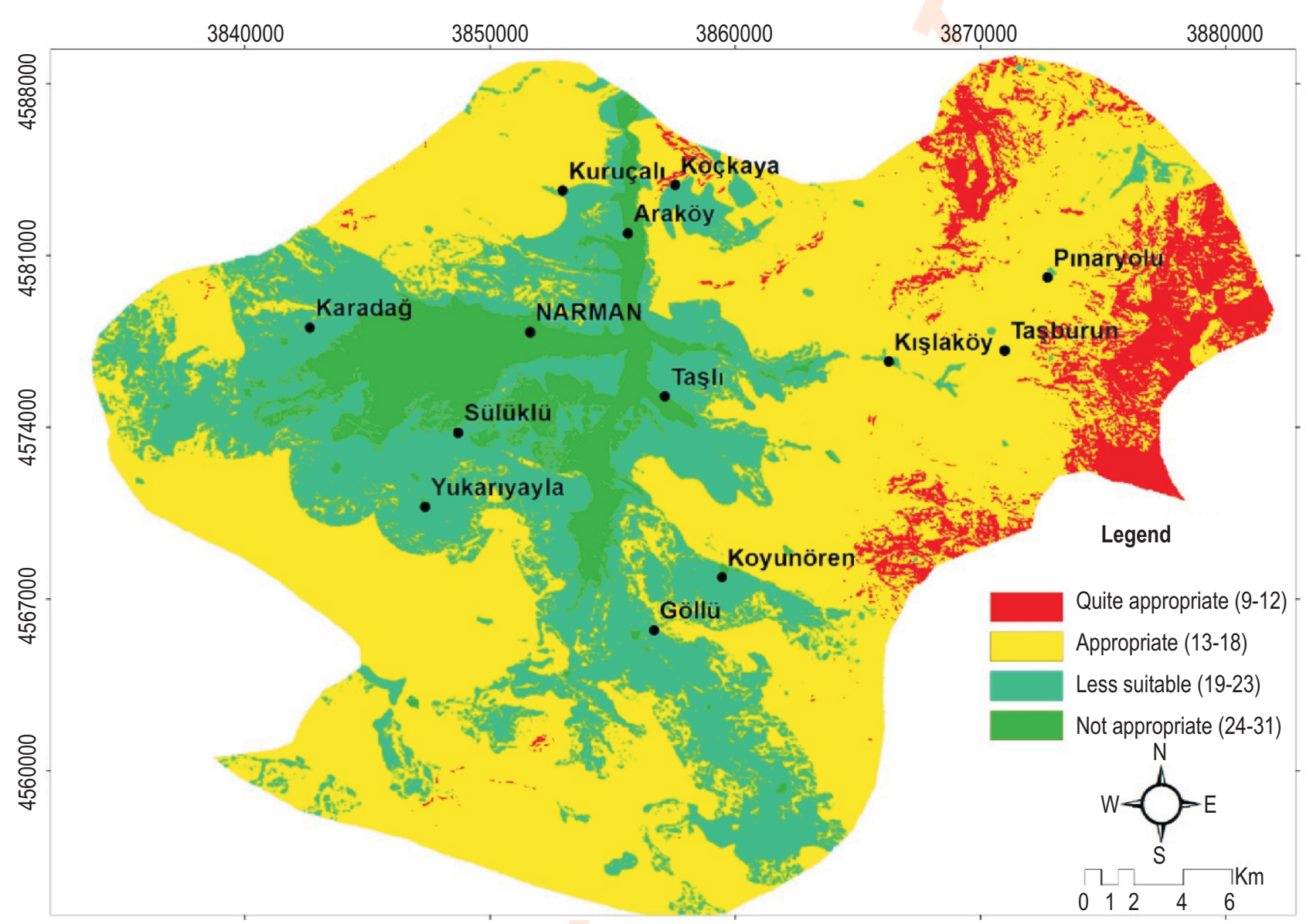

Fig. 4 : Map of potential ecotourism conformity values of the research area.

valley of the Çoruh River, among the massifs around the district center. The villages around the district are spread on the skirts of high massifs in the vicinity.

The climate of the district is warm compared to Erzurum because the district is located between high mountains. There are not much frost formation. Summers are hot and dry. Rain fall is usually during spring time. The district experiences the Black Sea climate as it is close to Black Sea Region.

Narman Fairy Chimneys are located $7 \mathrm{~km}$ to the southeast of district center, on the highway of Narman- Pasinler and covers an area of 6300 ha. The area attracts attention due to its red color and interesting earth shapes, also known as "the land of red-colored nymphs". Wind and rains have eroded the sandy soil, forming interesting landscape of red fairy chimneys and narrow valleys. These geological formations are seen only in this area in the East Anatolia. The valley is surrounded by the cities of Oltu, Şenkaya, Sarıkamış, Horasan, Pasinler and Tortum. These too attract attention because of their similarity with the Grand Canyon in America (Anonymous, 2018a). The tectonic movements; causing some partly folding and faulting; have played a major role in the present-day appearance of Narman area. Today the pressure-tectonic in the north-south direction of the region shows its effect (Yıldırım et al., 2012).

The interest of local and foreign tourists increases every year because the region was taken into the UNESCO Temporary 
List of World Heritage Sites in 2012 because of the Narman Fairy Chimneys with geological characteristics and natural beauty. The reason of red colour of Fairy Chimneys has been reported to have originated from the oxidation of iron in sediments as $\mathrm{Fe}_{2} \mathrm{O}_{3}$ (Anonymous, 2018b).

The stream network of the study area is composed of Narman water and its branches Büyükçay, Kamışözü and Bulanık streams. Ekreğin watercourse, which is a stream, formed by the sources in Başkale, Mercimekli and Güllü villages joins the Oltu Watercourse by merging with Narman Watercourse (Özav, 1987). The Red Fairy Chimneys located within the borders of eight different valleys is spread over an area of $63 \mathrm{~km}^{2}$ in the south and southeast of the Narman district, and are remarkable as the important forms of eruptions constituting the center of investigation area. This area has a unique characteristic, both scientifically and physically. In this study, 17 geosites and 56 unique inventories were recorded and 15 geoways were detected and mapped (Azaz and Güngör, 2017).

Except for large valley plain where the center of the district is established, other areas are quite mountainous. In the research area, Deve Mountain (2916 m), Kara Mountain (2930 m), Gök Mountain (2731 m), Telli Mountain (2589 m), Gaçarti Mountain $(2816 \mathrm{~m})$, Güllü Mountain (2893 m) and Büyük Mountain $(2800 \mathrm{~m})$ has interesting geological and geomorphological characters, while Narman, Boğakale and Şekerli highlands attract attention due to rich biodiversity (Anonymous, 2018a).

The settlement of the site dates back to 3000 years. There are 4 castles (Sami, Pertivan, Ignevut (Ergazi) and Başkale) in the town of Narman, Mehenk ruins and Yanıktaş (Ekrek) village of cultural loops extending from Central Asia to Anatolia, Akkoyunlu Cemetery and 2 Tombs (Ethembaba, Alibaba) (Cengiz and Akkus, 2012; Morkoç, 2013; Anonymous, 2018a).

Irano Turanian and Euro-Siberian phytogeographical elements are generally represented in the area. These are mostly distributed in the northern parts and on the slopes facing south of the district. Characteristic plants taxa representatives are; Acerdi vergens Pax var. divergens, Achillea wilhelmsii K. Koch, $A$. millefolium L., Aethionema grandiflorum Bois. \& Hohen., Alcea pallida Waldst. and Kit., Alyssum murale Waldst, Anthemis cretica L., Anthemis cretica L., A.tinctoria var. pallida., Calthapoly petala Hochst. exlorent, Campanula stevenii M. Bieb., Consolida orientalis (Gay) S., Coronilla orientalis Mill. var. orientalis, Crepis armena DC., Epilobium hirsutum L., Euphorbia virgate Waldst. Anchusalepto phylla Roemer and Schultes, Calthapoly petala Hochst. exlorent, Campanula stevenii M. Bieb., Consolida orientalis (Gay) S., Coronilla orientalis Mill. var. orientalis, Crepis armena DC., Epilobium hirsutum L., Euphorbia virgate Waldst. and Kit., Ferula communis L., Helichrysumarenarium L. Moench., Hypericum scabrum L., Linariagenistifolia (L.) Mill., Nepeta sp.,
Onobrychiscornuta L. Desv., Papaverdubium L., P.orientale L., Primulaveris L., Rhinanthusangu stifolius C.C. Gmelin, Rumexscutatus L., Seneciovernalis Waldst. \& Kit., Silena sp., Taraxacum sp., Tussilagofarfara L., Verbascumspeciosum Schrader., Veronica sp., Viciacannescens L., V. cracca L. subsp. cracca (Özav, 1987; Anonymous, 2018a).

Although Narman district has high natural and cultural resource value in terms of ecotourism, the resources have not be constructed with a sustainable planning approach. In order to determine the potential of region for ecotourism and establish a ground for the future sustainable tourism activities the assessment factors compliance maps were included (Fig. 3).

In order to determine the level of suitability of the district and its surrounding area to natural and cultural resource values of tourism and recreation activities of ecotourism, the compliance analysis of the assessment factors were made and mapped. The footprint and its proportions in the district were indicated (Fig. 2). As a result of overlaying of compliance maps, it was found that 9027 ha $(7.08 \%)$ of the district were quite appropriate for such activities, 79050 ha are (62\%) appropriate, 33379,5 ha $(26.18 \%)$ were less appropriate and 6043 ha (4.74 \%) were not appropriate (Table 2, Fig. 4).

Total area of the district was, "very appropriate" for ecotourism. The natural and cultural resource values of the area was 4083 ha, which constituted approximately 6\% of the investigation site. Especially, Narman Fairy Chimney and nearby areas, Ekreğin Watercourse, Narman Watercourses and Kuruçalı, Araköy, Taşı and Göllü villages close to those watercourses appeard appropriate areas with highest potential for ecotourism activities (Fig. 4). Given the ecological characteristics of the area, the region appeared to have rich vegetation, interesting geological and geomorphological formations and was surrounded by deep plains, separated by high mountains and rivers.

The "appropriate" areas in the district for tourism and recreation were predominantly located in and around active topography, flora and fauna, high mountainous areas, historical assets, lakes, rivers, villages and forests. These areas made up about $24 \%$ of the area and covered a total area of 17751 ha (Fig. 4). Especially, Narman Beşgöller has a unique natural beauty. Except for large valley plain on which the center of the district has been established, Deve Mountain, Karadağ, Gökdağ, Tellidağı, Gaçartidağı, Güllüdağ, Büyükdağ, Narman Plateau, Boğakale and Şekerli Highlands, and the areas and canyons attract attention with their geological and geomorphological characteristics in the region, where the lands are mountainous, and the rich biodiversity in this area is appropriate for ecotourism.

Apart from the rest and the areas which made up $26.18 \%$ of the district with 33379.5 ha were determined as "inappropriate" 
for ecotourism. The areas that constituted $4.74 \%$ of site with 6043.5 ha fields were identified as "not appropriate at all" (Fig. 4). These areas are defined as the areas where slope was not high, and considered as agricultural land, not including the forest areas, and the places that are not close to lakes and rivers were defined as dangerous areas for visitor's presence particularly in terms of natural habitat, and in this respect were determined as inappropriate for ecotourism.

In view of global economic, environmental and social changes taking place, it has been increasingly accepted by larger population day by day that the diversification lies in the use of rural areas with recreational tourism activities, which will have a greater impact both on local economy, on the rational and sustainable use of resources and on community health. Accordingly, studies to determine the appropriate usage types in an area are increasing and planning approaches come to the agenda with different analysis techniques. It is therefore important in terms of economical, environmental and social aspects that the positive developments experienced in the world find reflection in our country, which abounds in topographical and natural resource wealth such as natural vegetation and natural animal life, and in which traditional rural life qualities are protected to a great extent. With this approach, the number of studies carried out in different occupational disciplines in Turkey is increasing steadily. In order to ensure the sustainable use of natural resources, rural areas have been selected as research areas and are still being selected in the light of multi-dimensional developments. In previous studies, it has been emphasized that the rural areas with ecological, economical, climatic significance are important in terms of recreation-tourism activities and their use should be developed within the framework of healthy planning decisions. Producing and making the natural and cultural data of the area investigated during the spatial planning questionable using GIS tools effectively support the decision making process and facilitates the application of conformity analysis (Turoğlu, 2005; Cengiz et al., 2013).

As a result, we can say that the development of activities around the mountains, plateaus, agricultural areas, cultural heritages and ecotourism in the rural settlements can play an active role in the solution of problems and development of these regions in the long run. What is important in the regions opened for tourism is to preserve and protect handicrafts, architectural heritage and cultural heritage belonging to that region without abandoning the agricultural activities such as vegetable production, animal husbandry and forestry that have existed since years in the area. Tourism here should be complementary to agricultural activity in rural areas rather than being an alternative. Briefly, ecotourism should be implemented in an environmentally and ecologically sustainable way, should be economically applicable and socially acceptable and planning as well as understanding are important for this. Narman district selected as the investigation site by us is waiting to be discovered with its highlands, forests, waters, clean atmosphere and appropriate areas for ecotourism.

\section{References}

Aklibaşinda, M. and Y. Bulut: Analysis of terrains suitable for tourism and recreation by using geographic information system (GIS). Environ. Monit. Assess.186, 5711-5719(2014).

Akpinar Külekçi, E. and Y. Bulut: Determination of the most convenient ecotourism activity in the Oltu and Olur districts of Erzurum province by using analytic hierarchy process. Atatürk Univ., J. Agricult. Facul., 43, 175-189 (2012).

Anonymous: http://www.narman.bel.tr/llc/cografyasi.html (Access date: 18.06.2018), (2018a).

Anonymous: http://www.erzurumkulturturizm.gov.tr/TR, 174617/ narman-peri-bacalari. html (Access date: 03.06.2018), (2018b).

Anonymous: http://www.narman.gov.tr/ (Access date: 12.07.2018), (2018c).

Asur, F. and H. Alphan: Settlement suitability assessment and visual analysis approaches for southern coastal areas of the Van Lake. J. Inst. Sci. Technol., 7, 223-233 (2017).

Asur, F.:An Evaluation of visual landscape quality of coastal settlements: A Case Study of Coastal Areas InThe Van Lake Basin (Turkey). Appl. Ecol. Env. Res., 17, 1849-1864 (2019).

Azaz, D. and Y. Güngör: Geopark potential of Oltu - Narman (Erzurum) basin. 70th Geological Congress of Turkey. pp.106-117 (2017).

Cengiz, T., C. Akbulak, H. Özcan and H. Baytekin: Determination of optimal land use in Gökçeada. J. Agric. Sci., 19, 148-162 (2013).

Cengiz, G. and Ç. Akkuş: Development of local people within the scope of rural tourism: Example of Erzurum. K.M.U. J. Soc. Econ. Res., 14, 61-74 (2012).

Collins, M.G., F.R. Steinermichael and J. Rushman: Land use suitability analysis in the United States: Historical Development and Promising Technological Achievements. Environ. Manage., 28, 611-621 (2001).

Joerin, F., M. Theriault and A. Musy: Using GIS and outranking multi criteria analysis for land use suitability assessment. Int. J. Geogr. Inf. Sci., 15, 153-174 (2001).

Khoi, D.D. and Y. Murayama: Delineation of suitable cropland areas using a GIS based multi-criteria evaluation approach in the Tam Dao National Park region, Vietnam. Sustainability-Basel, 2, 20242043 (2010).

Kızıloglu, F.M., Y. Kuşlu, Ü. Şahin and S. Diler: Determination of optimum plant pattern in the irrigation area of Erzurum Daphan Plain by linear programming method. Atatürk Univ., J. Agric. Fac., 37, 73-80 (2006).

Kiper, T. and M. Arslan: A case study in the determination of nature walking routes within the scope of nature tourism in Anatolia. J. Tekir. Agri. Fac., 4, 165-174 (2007).

Kurdoğlu, O.: Nature Conservation Movement in the World: Its Historıcal Development and Present Situation. Artvin Coruh University J. For. Fac., 1, 59-76 (2001).

Laskar, A.: Integrating GIS and multi criteria decision making techniques for land resource planning. M.S. Thesis, International Institute for Geo-Information Science and Earth Observation. Enschede, 3, 106-112 (2003).

Makropoulos, C., D. Butler and C. Maksimovic: GIS supported evaluation 
of source control applicability in urban areas. Department of Civil and Environmental Engineering. Water Sci. Technol., 39, 123-129 (1999).

Malczewski, J.: GIS and Multicriteria Decision Analysis. John Wiley and Sons Inc., New York, pp. 29-36 (1999).

Malczewski J.: GIS-based land use suitability analysis: A critical over view. Prog. Plann., 62, 3-65 (2004).

McHarg, I.L.: Processes as Values. In design with nature. Published for The American Museum of Natural History, New York, pp. 279-286 (1992).

Moldovanyi, A.: GIS and multi-criteria decision making to determine marketability of pay pond businesses in West Virginia. Division of Forestry, West Virginia University, 3, 52-59 (2003).

Ocampo, L., J.A. Ebisa, J. Ombe and M.G. Escoto: Sustainable ecotourism indicators with fuzzy Delphi method-A Philippine perspective, Ecol. Indic., 93, 874-888 (2018).

Özbek, H.: Our Natural resources and Ornito in diversified tourism place.
T. C. Ministry of Tourism II. Tourism Declaration, 1, 101-109 (2004). Turoğlu, H.: Physical planning and geographic information systems. Ege University, Geography Department, Geographic Information Systems Symposium Proceedings Book, pp. 355-368, (2005).

Vural, $\mathrm{H} .:$ Landscape characteristics and rural tourism potential in Bingol Ilicalar town and its around. Bingol. Univ. J. Inst. Soc. Sci. Inst., 9, 12-17 (2019)

Wang, S.H., M.T. Lee, P.A. Chateau and Y.C. Chang: Performance indicator framework for evaluation of sustainable tourism in the Taiwan Coastal Zone. Sustainability-Basel, 8,1-7 (2016).

Yıldııım, G., A. Direnç, Y. Çelik and M. Yalçın: Investıgate the Potentıal of Being Jeopark of Narman Canyon (Narman-Erzurum) and Prepare of Geopark Inventory, Survey. Geol. Min. Ecol. Manag, 1,143-453 (2012).

Zengin, M. and S. Yilmaz: Determination of the use of Ardahan Kura River and its immediate surroundings and proposal of optimal area use. Atatürk Univ., J. Agri. Fac., 39, 43-54 (2008). 